\title{
Congenital malformation of lamina orbitalis ossis ethmoidalis
}

\author{
Kosuri Kalyan Chakravarthi', Nelluri Venumadhav' ${ }^{2}$, Siddaraju KS $^{3}$ \\ ${ }^{1}$ Department of Anatomy, Mayo Institute of Medical Sciences, Faizabad Road, Gadia, Barabanki, Uttar Pradesh, India, ${ }^{2}$ Department of \\ Anatomy, Melaka Manipal Medical College, Manipal University, Manipal, Karnataka, India, ${ }^{3}$ Department of Anatomy, KMCT Medical College, \\ Manassery, Calicut, Kerala, India
}

Background: The thinnest portion of the medial wall of the orbit is Lamina orbitalis ossis ethmoidalis which separates the ethmoidal sinuses from the orbit. Congenital bony malformation of orbit and anatomical variation of ethmoidal sinuses are important in terms of the risk of complication development during endoscopic sinus surgery and to understanding the pathophysiology and spread of sinus disease. Materials and Methods: Accordingly the present study was designed to find out the congenital malformation of medial wall of the orbit in relation to lamina orbitalis ossis ethmoidalis. The study was carried out using 100 dried adult human skulls and twenty six human cadavers irrespective of sex were obtained from the Department of Anatomy - Mayo Institute of Medical Sciences-Barabanki, Department of Anatomy - Melaka Manipal Medical College - Manipal and Department of Anatomy - KMCT Medical College, Manassery - Calicut. Results: In three skulls $(2.380 \%)$ we noted unilateral unusual hole at the junction of medial wall and roof of orbit with dimensions of $2.3 \mathrm{~cm}$ long and $1 \mathrm{~cm}$ height in two skulls and another unusual vertical hole at the anterior part of medial wall and roof of orbit with dimensions of $2 \mathrm{~cm}$ height and $1 \mathrm{~cm}$ width. We also noted few ethmoidal cells extended in to the orbital plate and fovea ethmoidalis of the frontal bone. Conclusion: Congenital defective formation of bony orbit and variable anatomy of paranasal sinuses noted in this study is may be due to the defective formation of Lamina orbitalis ossis ethmoidalis from the lateral part of the nasal capsule near the fronto ethmoidal suture such comprehensive knowledge is necessary to understand the various disorders of this region and to avoid complications during surgical procedures involving this area.

Key words: Ethmoidal air sinuses, Fovea ethmoidalis, Lamina orbitalis ossis ethmoidalis, Nasal cavity, Supraorbital ethmoid cells

\section{INTRODUCTION}

The orbits are conical or four-sided pyramidal cavities, which protects, supports, and maximizes the function of the eye. ${ }^{1,2}$ The thin medial wall of the orbit are formed anterior to posteriorly by frontal process of maxilla, lacrimal bone, ethmoid bone and lesser wing of sphenoid bone and is a poor anatomic barrier to infections of the paranasal sinuses with the potential complications of orbital cellulitis and abscess, optic neuritis and cavernous sinus thrombosis. Largest bony component of medial wall is formed by lamina orbitalis ossis ethmoidalis (orbital plate of ethmoid bone) which separates orbit from the nasal cavity. It articulates superiorly with the medial edge of orbital plate of frontal bone at fronto ethmoidal suture. An understanding of the anatomy of this region is the key to a number of operations like exploration of medial wall fracture, closure of cerebrospinal fluid leaks, external frontoethmoidectomy, orbital decompression, lateral rhinotomy, transethmosphenoidectomy and hypophysectomy. Thus the surgeons need to be more familiar with relevant anatomy and variations of bony 
orbit in relation to lamina orbitalis ossis ethmoidalis to avoid risk of complications while achieving operative procedures.

Precise understanding of anatomy of paranasal sinuses is an important prerequisite in avoiding complications during endoscopic sinus surgery. Among the paranasal sinuses the ethmoid sinus is often considered as the keystone of the sinus system because each paranasal sinus drainage pathway is through, or adjacent to its lateral wall. The ethmoid sinuses are divided into three groups, the anterior, middle and posterior group. The anterior ethmoidal cells drain into the infundibulum of the middle meatus, middle ethmoidal cells opens into the bulla ethmoidalis, while the posterior ethmoid cells drain into the superior meatus. ${ }^{3}$ Anatomical study of orbit is very important to ENT [Ear, Nose, and Throat] surgeons, ophthalmologists, oral and maxillo facial surgeons, neurosurgeons and forensic experts because of its proximity to the Para nasal sinuses. ${ }^{4}$ Highly complex and variable anatomy of paranasal sinuses is very important to avoid complications following endoscopic sinus surgery. ${ }^{5}$

Accordingly the present study was designed to find out the congenital malformation of medial wall of the orbit in relation to lamina orbitalis ossis ethmoidalis.

\section{MATERIALS AND METHODS}

The study was carried out using 100 dried adult human skulls and twenty six human cadavers irrespective of sex were obtained from the Department of Anatomy- Mayo Institute of Medical Sciences- Barabanki, Department of Anatomy- Melaka Manipal Medical College (MMMC)-Manipal and Department of Anatomy- KMCT Medical College, Manassery-Calicut. Medial wall of the orbit was macroscopically observed in skulls and in cadavers carefully dissected and reflected the orbital plate of the frontal bone after removing the calvaria or skull cap (with a bone saw), cerebral hemispheres and the congenital deformities or malformation of lamina orbitalis ossis ethmoidalis noted if any and representative anatomy was photographed for the proper documentation. The Instruments used for the cadaveric dissection were chisel, mallet, bone saw, bone cutter, bone retractor, scissors (straight and curved), and forceps (plain, toothed, pointed).

\section{RESULTS}

Among the 100 skulls and 26 cadavers we noted a very rare unilateral (left orbit) congenital defective formation of medial wall of orbit in relation to lamina orbitalis ossis ethmoidalis in three adult human skulls $(2.380 \%)$ (Figure 1 and 2), and whereas in the ninety seven adult human skulls and in cadavers medial wall of orbit in relation to lamina orbitalis ossis ethmoidalis was noted normal (Figure 3).

\section{Case 1 and 2}

Due to defective formation of lamina orbitalis ossis ethmoidalis (orbital plate of ethmoid bone) an unusual hole was noted at the junction of medial wall and roof of left orbit with dimensions of $2.3 \mathrm{~cm}$ long and $1 \mathrm{~cm}$ height (Figure 1).

\section{Case 3}

Due to defective formation of lamina orbitalis ossis ethmoidalis (orbital plate of ethmoid bone) and orbital plate of frontal bone an unusual vertical hole was noted at the junction of anterior part of medial wall and roof of left orbit with dimensions of $2 \mathrm{~cm}$ height and $1 \mathrm{~cm}$ width (Figure 2).

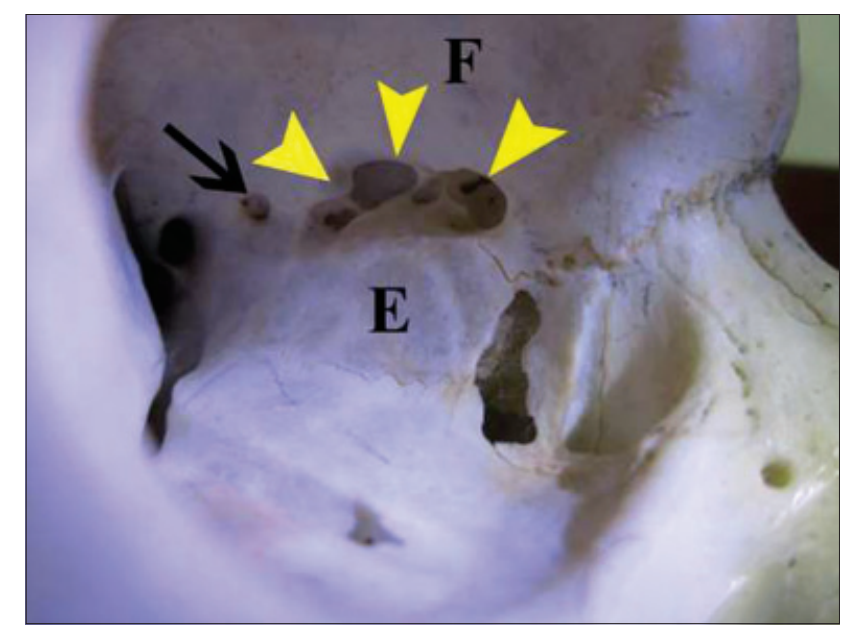

Figure 1: Showing unusual hole at the junction of medial wall and roof of left orbit. (F- Orbital Plate of frontal bone; E- lamina orbitalis ossis ethmoidalis; Black and Yellow arrows- Ethmoidal cells were extended in to the orbital plate of the frontal bone)

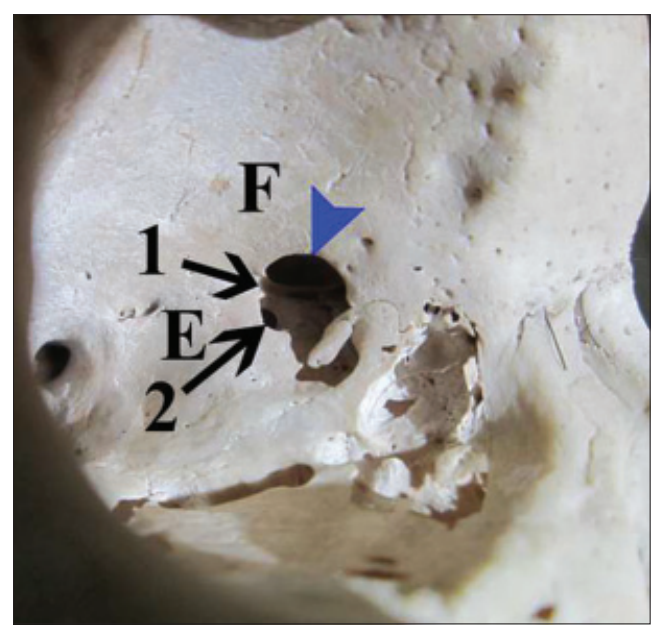

Figure 2: Showing unusual vertical hole of left orbit. (F- Orbital Plate of frontal bone; E- lamina orbitalis ossis ethmoidalis; 1- Opened Anterior ethmoidal foramen and canal; 2- Communication between posterior and middle ethmoidal cells; Blue arrow-Ethmoidal cells were extended in to the orbital plate and fovea ethmoidalis of the frontal bone) 


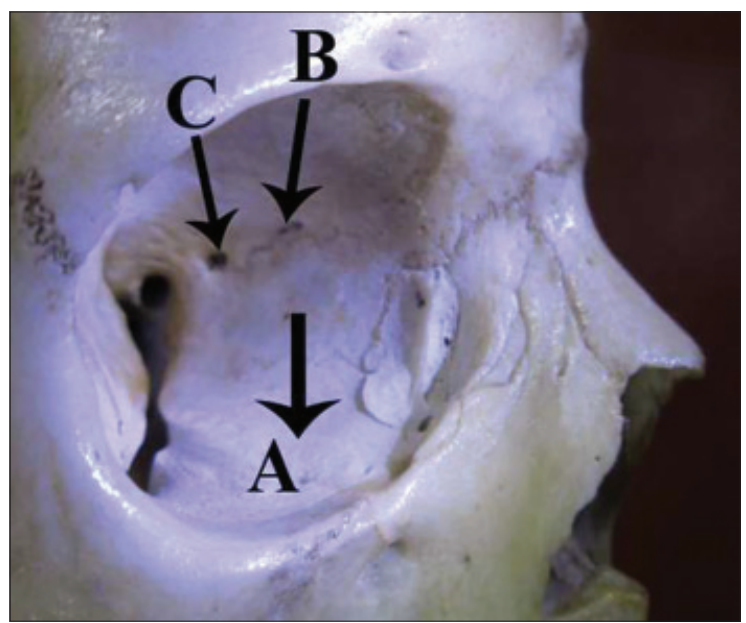

Figure 3: Showing normal medial wall of left orbit. (A- Lamina orbitalis ossis ethmoidalis; B-Anterior ethmoidal foramen; C- Posterior ethmoidal foramen)

We also noted few ethmoidal cells were extended in to the orbital plate and fovea ethmoidalis of the frontal bone (supraorbital ethmoid cells) (Figures 1 and 2).

\section{DISCUSSION}

The ethmoid bone consists of horizontal or cribriform plate, forming part of the base of the cranium; a perpendicular plate, constituting part of the nasal septum; and two lateral masses or labyrinths. The Labyrinth or lateral lass consists of a number of thin-walled cellular cavities, the ethmoidal cells which are arranged in three groups (anterior, middle, and posterior) and interposed between two vertical plates (lateral and medial plates) of bone. The lateral plate (lamina orbitalis ossis ethmoidalis or orbital plate of ethmoid bone) is the thinnest portion which forms part of the medial wall of the orbit and the lateral wall for the ethmoidal labyrinth which separates the ethmoidal sinuses from the orbit. Lamina orbitalis ossis ethmoidalis articulates superiorly with the medial edge of orbital plate of frontal bone by fronto ethmoidal suture. Along the fronto ethmoidal suture anterior and posterior ethmoid foramina lay through these foramina anterior and posterior ethmoid arteries (branches of ophthalmic artery) and nerves (branches of naso ciliary nerve) pass and are important surgical landmarks. This suture forms the approximate level of ethmoidal sinus roof any dissection above this suture line will expose the cranial cavity. Knowledge of course of anterior and ethmoid artery is very important for surgeons. ${ }^{6}$ An unusual hole at the place of fronto ethmoidal suture noted in this study may leads to abnormal course of the anterior ethmoidal artery such comprehensive knowledge of the anatomical characteristics of orbit in relation to Lamina orbitalis ossis ethmoidalis can increase the success of diagnostic evaluation and surgical approaches to the region.
The ground or basal lamella of the middle nasal concha separate the anterior and the posterior ethmoid cells, by creating a bony septation that dictate the drainage pattern of the anterior ethmoid cells into the middle meatus and for the posterior ethmoid cells into the superior or supreme meati. Thus basal lamella of the middle nasal concha represents the surgical posterior limit for an anterior ethmoidectomy. Anatomic variations of ethmoid cells have been reported ${ }^{7-9}$ whereas anterior, middle and posterior ethmoid cells communications with each other through unusual hole noted in this study such congenital malformation of bony orbit have not been reported in the modern medical literature. Such variable bony orbit anatomy helps in understanding the pathophysiology and spread of sinus disease, as well as performing the most complete ethmoid surgery with the least surgical complications. ${ }^{10-12}$

The fovea ethmoidalis and lateral lamella most vulnerable bone of the skull base ${ }^{13,14}$ are the most important parts of the skull base in terms of the risk of complication development during endoscopic sinus surgery. ${ }^{15,16}$ The fovea ethmoidalis a part of the frontal bone forms the roof of the ethmoid labyrinth and separates the ethmoidal cells from the anterior cranial fossa. Ethmoid cells are present within the bony labyrinth or lateral mass of the ethmoid bone where as in this study few ethmoidal cells were extended in to the orbital plate and fovea ethmoidalis of the frontal bone, which may referred as supraorbital ethmoid cells or suprabullar cells. During endoscopic sinus surgery supraorbital cells can be mistaken for the frontal sinus by inexperienced surgeons. Asymmetry in the anterior of the skull base and especially in the ethmoid roof is important, in asymmetry the height of the ethmoid roof varies, and the fovea ethmoidalis of the two sides may be at different levels. Intracranial complications appear more frequently on the side in which the ethmoid roof is low. This low-hanging roof may cause cerebrospinal fluid fistula and recurrent meningitis postoperatively. ${ }^{17,18}$

The medial rectus lies close to the lamina papyracea it may injured or entrapment or may compress it's nerve or vascular supply at the unusual fissure noted in this case and results in characteristic divergent strabismus and almost absent adduction. The orbital fat and the medial rectus muscle often protrude (herniate) through this gap into the nasal cavity. Thus a comprehensive knowledge of orbital and peri orbital anatomy is necessary to understand the various disorders of this region and in its surgical management. The ethmoid is ossified in the cartilage of the nasal capsule by three centers one for the perpendicular plate, and one for each labyrinth. Lamina orbitalis ossis ethmoidalis and ethmoidal labyrinth were ossified from the lateral part of 
the nasal capsule, whose spaces communicate with the nasal cavity and become filled with air after birth. Unusual fissures noted in this study may be due to the defective formation of Lamina orbitalis ossis ethmoidalis from the lateral part of the nasal capsule near the fronto ethmoidal suture.

The anatomy of the orbit and periorbital region is complex, congenital malformations or anomalies of human orbit anatomy are important in diagnosis and treatment of patients with orbital/periorbital disease. Infections from the ethmoidal air-cells can easily get into the orbit through the unusual fissure noted in this case and affect the orbital contents may cause severe orbital complications. Increased pressure within the nasal cavity during sneezing may leads to temporary exopthalmos. Congenital malformation of lamina orbitalis ossis ethmoidalis noted in this study may permits communication between the nasal cavity and the ipsilateral orbit, resulting in orbital emphysema or the infections may enter the sterile environment of the central nervous through the holes in the cribriform plate.

\section{CONCLUSION}

Knowledge of orbital anatomy is very important during advanced endoscopic skull base surgical procedures, ENT [Ear, Nose, and Throat] surgeons, ophthalmologists, neurosurgeons, forensic experts, and oral and maxillo facial surgeons, because of its proximity to the para nasal sinuses. Congenital defective formation of bony orbit and variable anatomy of paranasal sinuses noted in this study is necessary to understand the various disorders of this region and to avoid complications during surgical procedures involving this area.

\section{ACKNOWLEDGMENT}

I am deeply grateful to Dr. K. N. Singh [Chairman- Mayo Institute of Medical Sciences Faizabad Road, Gadia, Barabanki] and Dr. Prakash V. Patil [Principal/Dean, Mayo Institute of Medical Sciences], for their constant support and guidance.

\section{REFERENCES}

1. Moore, Keith L. Clinically Oriented Anatomy. $6^{\text {th }}$ ed Lippincott Williams \& Wilkins, 2010.
2. Duane's Ophthalmology, Chapter 32 Embryology and Anatomy of the Orbit and Lacrimal System. (Eds Tasman W, Jaeger EA) Lippincott/Williams \& Wilkins, 2007.

3. Otorhinolaryngology, Head and Neck Surgery, Anniko, Springer, 2010, pp 188.

4. Patnaik VVG, Sanju B and Rajan K S. Anatomy of the bony orbits- Some applied aspects. Journal of the Anatomical Society of India 2001; 50(1):59-67.

5. Thiagarajan B. Anatomy of Paranasal sinuses [Internet]. Version 9. Ent Scholar. 2012 Nov 8. Available from: http://entscholar.wordpress.com/article/anatomy-ofparanasal-sinuses/.

6. Gupta AK, Bansal S and Sahini D. Anatomy and its variations for endoscopic sinus surgery. Clin Rhinol An Int J 2012; 5:55-62.

7. Kaplanoglu H, Kaplanoglu V, Dilli A, Toprak U and Hekimoglu B. An Analysis of the Anatomic Variations of the Paranasal Sinuses and Ethmoid Roof Using Computed Tomography. Eurasian J Med 2013; 45: 115-125.

8. Beale TJ, Madani G and Morley SJ. Imaging of the paranasal sinuses and nasal cavity: normal anatomy and clinically relevant anatomical variants. Semin Ultrasound CT MR 2009; 30: 2-16.

9. Keast A, Yelavich S, Dawes $P$ and Lyons B. Anatomical variations of the paranasal sinuses in Polynesian and New Zealand European computerized tomography scans. Otolaryngol Head Neck Surg 2008; 139: 216-121.

10. Rice DH and Schaefer SD, Anatomy of the Paranasal Sinuses. In: Rice DH, Schaefer SD (2004) Endoscopic Paranasal Sinus Surgery. Lippincott Williams \& Wilkins, $3^{\text {rd }}$ edn.

11. StammbergerHR and Kennedy DW. Paranasal sinuses: anatomic terminology and nomenclature. The Anatomic Terminology Group. Ann Otol Rhinol Laryngol Suppl 1995; 167:7-16.

12. Wormald PJ. The agger nasi cell: The key to understanding the anatomy of the frontal recess. Otolaryngol Head Neck Surg 2003; 129:497-507.

13. Stammberger HR and Kennedy DW; Anatomic Terminology Group. Paranasal sinuses: Anatomic terminology and nomenclature. Ann Otol Rhinol Laryngol Suppl 1995; 167: 7-16.

14. Terrier F, Weber W, Ruefenacht D and Porcellini B. Anatomy of the ethmoid: CT, endoscopic and macroscopic. AJR Am J Roentgenol 1995; 144: 493-500.

15. Kainz $\mathrm{J}$ and Stammberger $\mathrm{H}$. The roof of the anterior ethmoid: a locus minoris resistentiae in the skull base. Laryngol Rhinol Otol (Stuttg) 1998; 67: 142-149.

16. Ohnishi T, Tachibana T, Kaneko $Y$ and Esaki S. High-risk areas in endoscopic sinus surgery and prevention of complications. Laryngoscope 1993; 103: 1181-1185.

17. Kizilkaya E, Kantarci M, Cinar Basekim C, Mutlu H, Karaman B, Dane S, et al. Asymmetry of the height of the ethmoid roof in relationship to handedness. Laterality 2006; 11: 297-303.

18. Reib $M$ and Reib G. Height of Right and Left Ethmoid Roofs: Aspects of Laterality in 644 Patients. Int J Otolaryngol 2011; 1-4: Article ID 508907. 